\title{
Consequences of Land Use Changes on Hydrological Functioning
}

\author{
Luc Descroix and Okechukwu Amogu \\ IRD / UJF-Grenoble 1 / CNRS / G-INP, LTHE UMR 5564, LTHE, \\ Laboratoire d'études des Transferts en Hydrologie et Environnement,
}

France

\section{Introduction}

Land use and land cover changes are well known to have a strong influence on the water cycle and its evolutions. Vegetation cover is the main component of the land surface that explains the behaviour of rainwater transforming into runoff, infiltration or evapotranspiration. Land use changes such as afforestation or deforestation, increase in cropping or grazing areas, likely modify this water balance and land surface behaviour. However, urbanisation and sometimes some geopolitical events, could significantly influence the water cycle.

Human activities that change the land cover can considerably change the water cycle within a basin; for example, the present-day situation of the Aral Sea basin in Central Asia where intensive irrigation resulted in a near cessation of the water inflow from the Syr Daria and the Amu Darya rivers. In the Mediterranean basin and the Sahel, the successive removal of vegetation by forest clearing and overexploitation increased drought risks. Inversely, the increase in frequency of flooding in the Ganges basin can be explained by deforestation (Kuchment, 2008). Furthermore, dams and reservoirs dedicated to irrigation increase evaporation and decrease the transport of sediments.

In the following sections, we will describe the main changes observed in the water cycle in different areas. Firstly, we will compare the hydrodynamic changes in two different mountainous areas subject to very different socio-economic changes in the recent decades and centuries. As "water towers", mountains are the natural reservoir and providing areas for most of the semi-arid and arid regions in the World with the land use and land cover changes in these areas causing changes in water supply in the downstream plains. Secondly, we will compare two different areas in West Africa in the current period in order to highlight the role of soil hydrological functioning from the primary scale to the regional scale. The non-linearity of hydrological processes in this area gives rise to the "Sahelian paradox" as the anthropic impact exceeds the influence of the climatic inter decadal signal. LUC/LCC (land use change/land cover change) not only lead to consequences in hydrological balances, but also in sedimentary balance. Land cover has a direct influence on soil erosion and conservation. Both erosion and runoff determine the river transport capacity, whose evolution appears as geomorphic evidences of the historical behaviour of the basins. In a third section, we will 
describe the consequence of land use changes in erosion, transport and sedimentation processes; finally, other causal factors of water cycle modifications will be discussed in the last part of this chapter.

\section{Consequences}

Mountainous areas are commonly characterized by forests, whose removal reduces infiltration and improves the conditions of overland flow (Kuchment, 2008). As a consequence, flood runoff and peak discharges may significantly increase. On the contrary, the main effect of afforestation on the water cycle is an increase in transpiration and interception of precipitation, which in turn results in a decrease of the volume of total discharge. Simultaneously, the higher infiltration capacity of forest soils increases the opportunity for groundwater recharge, and the flow of small rivers tends to be more sustained.

In this section, the hydrological behaviours of two different mountains are compared.

The French Southern Alps constitute a mountain area in stage of resilience. This region suffered up till the end of the 19th century from severe land degradation due to deforestation, crops extension and overgrazing. Large areas and hillslopes were degraded and numerous "torrents" appeared. Floods and inundations in the alpine valleys and in the downstream flood plains were frequent and devastative. Flood flows increased and on the contrary, base flows were reduced, making water management very difficult. A strong increase in soil losses in the upstream part of the basins led to river beds widening and rising. As in other mountainous areas of Southern Europe, a hard policy of land reclamation was initiated in the second half of the 19th century (French $2^{\text {nd }}$ Empire and $3^{\text {rd }}$ Republic). Reforestation and torrent correction were strongly developed (Table 1); then, socioeconomic evolution and three wars (against Prussia in 1870, and the $1^{\text {st }}$ and $2^{\text {nd }}$ World Wars) depleted these areas of their inhabitants (Descroix \& Gautier, 2002; Descroix \& Mathys, 2003).

\begin{tabular}{|l|c|c|c|c|c|c|c|}
\hline \multirow{2}{*}{ Department } & $\begin{array}{c}\text { total area } \\
\left(\mathrm{km}^{2}\right)\end{array}$ & \multicolumn{5}{|c|}{ Forested area (\%) } & $\begin{array}{c}1992 \text { forested area } \\
\text { in 1992 }\left(\mathrm{km}^{2}\right)\end{array}$ \\
\hline Alpes Hte Provence & 6954 & 10 & 18 & 26 & 31 & 36 & 2500 \\
\hline Hautes Alpes & 5534 & 11 & 19 & 27 & 29 & 34 & 1860 \\
\hline Drôme & 6560 & 15 & 23 & 29 & 31 & 43 & 2800 \\
\hline
\end{tabular}

Table 1. Evolution of the forested area in the three French Southern Alps districts since 1770

\begin{tabular}{|l|c|c|}
\hline Bed rock outcrop & soil losses in mm.yr ${ }^{-1}$ & number of sites documented \\
\hline Black marls & 9.4 & 13 \\
\hline Blue marls & 8.6 & 4 \\
\hline Grey marls & 8 & 1 \\
\hline Molasses & 1.4 & 1 \\
\hline Glacial fields & 16 & 1 \\
\hline Oligocene clays & 30 & 1 \\
\hline
\end{tabular}

Table 2. Measured erosion depth in the main fragile outcrops in Southern French Alps 
The most important sediment providing material in the French Southern Alps is the black marls (Table 2), which outcrops exceed $1000 \mathrm{~km}^{2}$; but some other fields are also very sediment productive, as indicated in Table 2 . For centuries, these very degraded marly terrains were providing stream flow and suspended sediment load to the Alpine rivers.

Nowadays, the forested area is more than three times that of the mid 19th century, and erosion is no more a concern for the population neither is the flood, and inundation has become very uncommon in the last few decades. Flooding and sedimentation are now very sparse and they are no more a constraint to development either for agriculture or for other socio-economic activities. The Durance river valley was completely developed during the $20^{\text {th }}$ century and a series of dams were built along the river in order to provide electric power as well as water to the irrigated district of the lower Provence and the Comtat Venaissin and for the cities of Marseille and Toulon.

Inversely, in Northern Mexico, the hillslopes of the Western Sierra Madre have for some decades been going through a great erosion stage. This is due to a generalised overexploitation of the environment. This area has been characterized at least since the 1970s by a general overgrazing and forest clearing in the upper part of the basins (Descroix et al., 2002, Viramontes \& Descroix, 2003). Both human originated processes cause an increase in bare soils areas, leading to soil compaction and a significant decrease in soil hydraulic conductivity and water infiltration. Other consequences are a decrease in soil water holding capacity and an increase in runoff. Instead of gullies, this area is characterised overall by sheet erosion and sheet runoff, all the soil surface being degraded: fine soil particles are removed by drop detachment and transported by runoff. This decrease in soil permeability is demonstrated by data collected in Table 3 and Table 4 . At the end of the $20^{\text {th }}$ century, deforestation was severe and more than $50 \%$ of the extended pine and oak forests of the upper parts of the Sierra had already been cleared, with the exploited wood volume being commonly three times higher than the authorized volume (Viramontes \& Descroix, 2003). Measurements made at the $50 \mathrm{~m}^{2}$ plot scale show that runoff was increased by one order of magnitude and erosion by two orders of magnitude after the tree cutting (Table 3). In the first years following clearing, the remaining litter partially protects the soil.

\begin{tabular}{|l|c|c|}
\hline Plot characteristics & runoff coefficient (\%) & soil losses $\left(\mathrm{g} \cdot \mathrm{m}^{-2}\right)$ \\
\hline Non cleared plot & 2.8 & 1.1 \\
\hline Cleared plot with remaining litter & 8.5 & 30 \\
\hline Cleared plot without litter & 23 & 133 \\
\hline
\end{tabular}

Table 3. Influence of clearing on runoff and erosion measured at the plot scale $\left(50 \mathrm{~m}^{2}\right)$ in a forest environment in the Western Sierra Madre (Northern Mexico)

In the same upper part of the Sierra Madre, soil physical characteristics were measured on grassland areas, in order to compare their behaviour in non grazed or normally grazed areas on the one hand, and in spread overgrazed sectors on the other hand. Obviously, overgrazing causes a strong increase in runoff (five times higher) and erosion (one order of magnitude higher), and a significant reduction in hydraulic conductivity and soil porosity and inversely a rise in soil bulk density (Table 4). The three latter parameters are part of the explaining factors of the two former ones. They are due to cattle trampling which provokes soil compaction and a closing of the pores, most of them becoming inactive (Descroix et al., 2002). 


\begin{tabular}{|l|c|c|c|c|c|}
\hline $\begin{array}{l}\text { Soil } \\
\text { characteristics }\end{array}$ & $\begin{array}{c}\text { runoff } \\
\text { coefficient } \%\end{array}$ & $\begin{array}{c}\text { soil losses } \\
\text { g.m }{ }^{-2}\end{array}$ & $\begin{array}{c}\text { hydraulic } \\
\text { conductivity } \mathrm{mm}^{-1} \mathrm{~h}^{-1}\end{array}$ & $\begin{array}{c}\text { bulk density } \\
\text { g.cm }\end{array}$ & $\begin{array}{c}\text { Porosity } \\
\%\end{array}$ \\
\hline Non grazed & 8 & 7 & 77 & 1.21 & 49 \\
\hline Overgrazed & 43 & 90 & 24 & 1.55 & 35 \\
\hline
\end{tabular}

Table 4. Soil characteristics on non-grazed and overgrazed areas in a grassland environment. Runoff and erosion measured on $50 \mathrm{~m}^{2}$ and $1 \mathrm{~m}^{2}$ plots (10 repetitions per class); hydraulic conductivity measured with disk infiltrometer, bulk density by the "pool method", porosity using a mercury porosimeter.

Thus, we observed in the last 3 decades the following features at the basin scale (those of Rio Ramos and Rio Sextin, two tributaries of the Rio Nazas, whose catchment areas are respectively 7100 and $4700 \mathrm{~km}^{2}$ ) (Fig.1):

- $\quad$ a reduction of the basin lag time to precipitations

- a reduction of the total duration of river flow

- $\quad$ an exaggeration of the flood peak

- $\quad$ an increase in flood flow

- $\quad$ and a decrease in base flow

\section{Reduction of the lag time \\ Reduction of the total duration of flood}

Exaggeration of flood peak

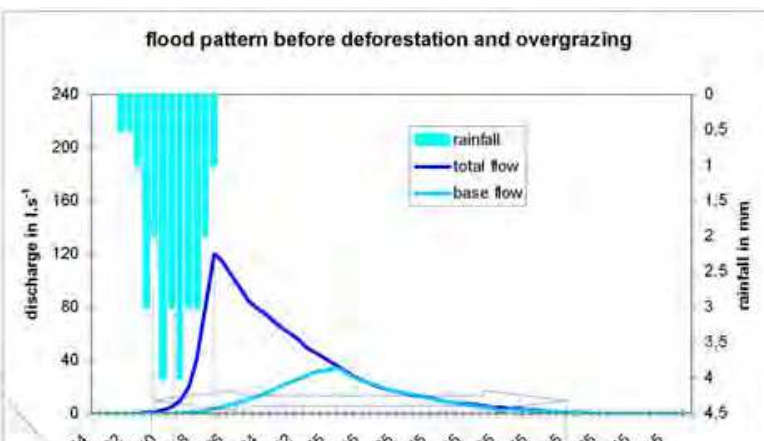

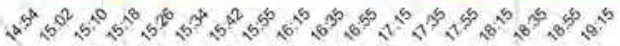

flood pattern after deforestation and overgrazing

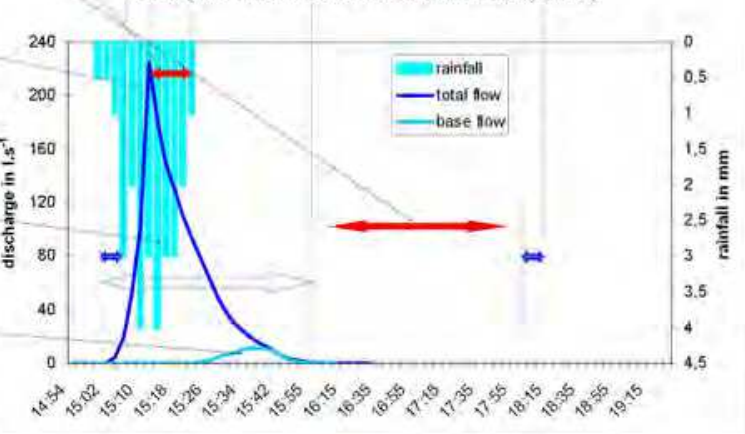

Fig. 1. Observed hydrological changes linked to land use changes by the evolution of hydrographs in sub-basins of some $\mathrm{km}^{2}$ into the Ramos and Sextin Rivers basins 
All these facts are the results of a reduction of the water holding capacity of the soils and the basins.

These consequences make water management more difficult, because there is less water in the rivers during the dry season, at the moment where water is most required for agriculture, grazing and other needs. Simultaneously, the increase of the discharge, the peak flow and the flooding risk during the rainy season also makes water management more difficult due to both the necessity to increase the volume of reservoirs to ensure the same volume of supplied water and the severe increase in silting up which could cause other problems as dam sedimentation, and local difficulties for irrigation and navigation.

This will also have consequences in the sediment balance (see part 4).

Land cover highly impacts the water cycle; this is even more marked in mountainous areas where there is commonly more rainfall, and steep slopes favourable to runoff and erosion. Mountains being natural water towers, land use and land cover changes could have there consequences in the water balance of extended areas. Processes described in fig.1 applied at the scale of great water providing areas could lead considerable changes in water supply and oblige to great water management modification. In sub-Saharan Africa, two main water towers (the Guinean mountains and the Ethiopian Highlands) provide water to hundreds of millions inhabitants, with significant proportion of them living in arid and semi-arid areas. An increase in both flood and drought hazards is observed from some decades and this is a threat for the downstream located societies. This is also a geopolitical challenge, and water scarcity could be in the future the cause of severe conflicts.

\section{The sahelian paradox}

In the West African Sahel, it was observed in recent decades that during the Great Drought that occured in this region (this has not yet come to an end, although rainfall amounts are partially increasing again; see Ali and Lebel, 2009 and Lebel and Ali, 2009), Sahelian rivers showed a significant increase in runoff in spite of the reduction of the annual rainfall amount. Since this cannot be due to rainfall, there is a consensus to estimate that this is a consequence of land use change (Albergel, 1987; Descroix et al., 2009; Amogu et al., 2010). West Africa suffered a great drought from 1968 to 1995. The Sahelian area (semi-arid part of West Africa, with annual rainfall lower than $700 \mathrm{~mm}$ ) was more particularly affected with a decrease in rainfall ranging from 20 to $35 \%$ during the 1970s and the 1980s compared with the 1950-1968 period. The drought has not really ended, only attenuated in the eastern half of the Sahel, and rainfall remains very low in its western part (Ali and Lebel, 2009; Lebel and Ali, 2009).

The large rivers of West Africa (Senegal, Gambia, Niger, Chari among others) experienced an expected decrease in discharge since the beginning of the Drought (1968); for the period of 1970-2000, the decrease in the mean annual discharge of the region's largest rivers (fig.2), namely the Senegal and Niger rivers, was in proportion almost twice as much as the decrease in rainfall. Similar trends have been observed for smaller river systems while, in contrast, other studies have indicated a runoff increase in some Sahelian catchments. Albergel (1987) remarked a paradoxical fact: although the rainfall was decreasing from 1968, runoff increased in experimental Sahelian catchments in Burkina Faso; in the Sudanian catchments of the same country, more classically, the discharges were decreasing. This is even more paradoxical because rainfall decreased stronger northward, in the Sahelian area, 
than in the Sudanian one (Fig. 3). Amani and Nguetora (2002) highlighted an increase in runoff of some right bank tributaries of the Niger River, and they observed that their flood began one month earlier during the 1980s than during the 1960s; they also remarked that in the Niger River at Niamey station, sometimes in the recent years (at the moment) the first flood peak was higher than the "guinean flood" peak, a process that never occurred before 1984. Mahé et al. (2003) observed an increase in discharge of the Nakambé River, one of the upper Sahelian tributaries of the Volta River; Mahé and Paturel (2009) noticed an increase in runoff coefficients and in discharges in the Black and White Gorgol basins in the western Sahel (Mauritania). This is also observed in the south Sahelian Sokoto basin in Nigeria (Mahé et al., 2011). Most of the Sahel seems to be concerned by this "Sahelian paradox". Amogu et al (2010) proposed a regionalisation of hydrological processes, with a big difference between Sudanian areas where runoff decreased strongly and Sahelian (and, in recent years, north-Sudanian) areas where runoff increased significantly. They also determined that this increase in runoff was observed at all the spatial scales.

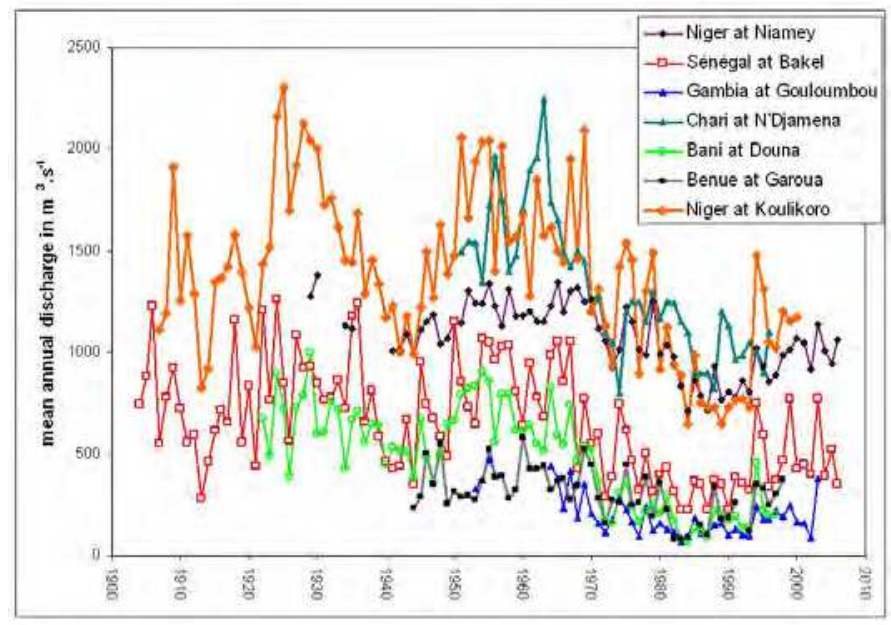

Fig. 2. The effect of the Great Drought on the discharge of the main West African rivers: a general expected decrease in runoff after 1968

Until the end of the 1990s, all the water supplied to the Niger River downstream from Gao came from the right bank tributaries. On the left bank, endorheism is the main hydrological mode, and the observed increase in runoff led to an increase in the number, the volume and the duration of ponds. As the ponds are the main groundwater recharge points, this caused a significant increase in groundwater recharge and a rise in water table level in the western part of the Iullemeden sedimentary basin, during the drought; this was named the "Niamey's paradox" by Leduc et al (1997) and described by Séguis et al. (2004). Also in this case, the increase in runoff is supposed to be due to land use change, particularly land clearing (Leblanc et al., 2008). Finally, if the drought is the most cited process in the Sahel, "floods in drylands" are not to be considered as an oxymoron, and they are unfortunately not well known, in spite of their current rise in number and strength (Tschakert and al., 2010). 


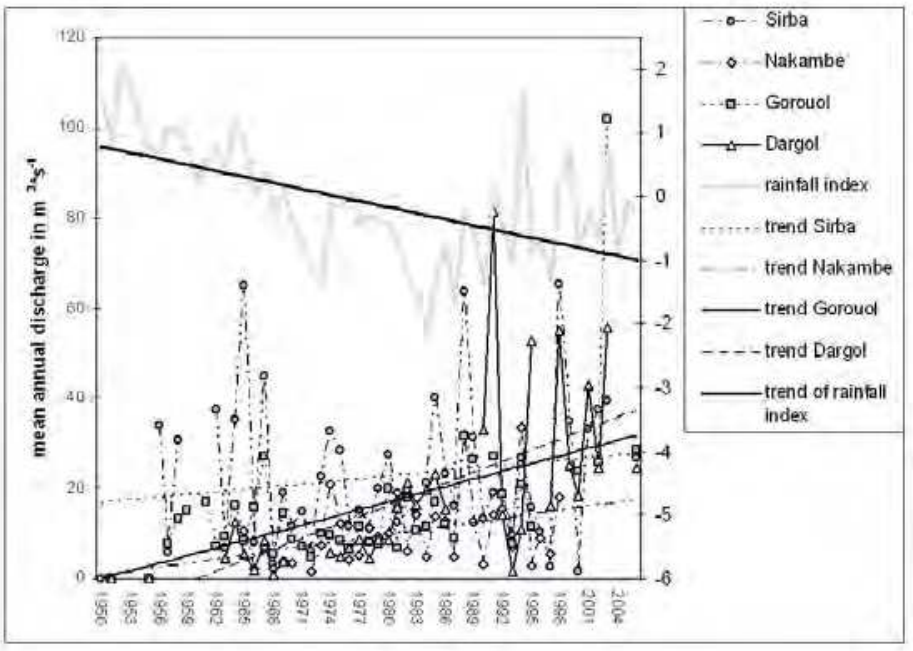

Fig. 3. The unexpected increase in discharge of gauged Sahelian rivers during the Great Drought

Most of the changes in the water cycle characteristics in West Africa result from the long drought period (observed since 1968) and the reduction of the soil water holding capacity. However, recent studies (Mahé et Paturel, 2009, Descroix et al., 2009) have shown that anthropic factors better explain the spatial and temporal variability of the processes than the climatic factors.

As a matter of fact, as in all geo-climatic environments, a combination of natural and human parameters leads to changes in processes, which explains the resource evolution and possibly, as a feed back effect, the climatic evolution; but the last hypothesis remains to be founded on tangible evidence. The combined action of the very clear climatic and anthropic trends led to the following hydrological consequences (Albergel, 1987, Mahé, 1993, Amani et Nguetora, 2002, Mahé et al, 2003, Mahé et al, 2005, Andersen et al., 2005, Mahé, 2009, Mahé et al, 2009, Amogu, 2009, Descroix et al., 2009, Amogu et al., 2010; Descroix et al. 2012):

- An increase in runoff and river discharge in the Sahelian region (fig.3), linked to the partial removal of vegetation cover and to the soil crusting in increasingly widespread areas, causing a reduction of the soil water holding capacity; runoff becomes mostly of the "hortonian" type (produced when rainfall intensity exceeds the soil infiltration capacity) (Horton, 1933); as this increase in runoff occurred during the great drought, it is called the "hydrological Sahelian paradox";

In the Sudanian region, where the rainfall deficit was lower, an inverse trend has long been observed, and runoff and discharge were logically and expectedly decreasing with the reduction in rainfall. Hydrological processes remain there mostly "hewlettian" (Hewlett, 1961, Cappus, 1960), i.e. runoff occurs only when the soil is saturated; as soils are mainly deep, the reduction of rainfall firstly affected the part of water which was dedicated to runoff (fig.4). The increase in runoff is not observed in the Sudanian area (where rainfall 
amount ranges from 700 to $1300 \mathrm{~mm}$ per year), where the reduction in rainfall was not so strong (10-15\%) due to lower land use changes and a reduced impact of these changes. With soils being deeper in this area, the important role of soil and groundwater in runoff yield is highlighted. In this "hewlettian" context, a decrease in rainfall firstly reduces the part dedicated to runoff.

- In the north of the Sudanian area, the evolution of discharges is intermediate between the two previous ones described above; the discharge seems to be unchanged (Fig. 5). This can be explained by the development of "horton-type" processes due to land clearing and associated soil crusting, in an area which remained relatively void of inhabitants for a long time (due to sanitary and historical reasons).

- A decrease in the discharge of the main regional rivers (Gambia, Senegal, Niger, Volta, Chari) (fig.3); their main water sources originate in the sudano-guinean area more than in the sahelian region, although their basins extend into the sahelian area (Niger, Sénégal); therefore, the increase in sahelian runoff does not compensate the reduction in Sudan-originated flows. Thus, the discharge of the Niger River at Koulikoro (in Mali, upstream from the Niger Inner Delta -NID-) was halved during the last three decades of $20^{\text {th }}$ century (Olivry, 2002; Andersen et al., 2005).

- In certain endorheic areas of the Sahel, the increase in runoff caused for some decades a rise in the number of ponds, of their volume and their duration; while these ponds were defined as the main recharge area for groundwater, a significant rise in water table level was observed (Leduc et al., 1997; Leblanc et al., 2008). Recently it was determined that the sandy deposits linked to the acceleration of soil erosion (gully bottoms, spreading areas, dejection fans, etc) are new recharge areas in extension (Descroix et al., 2012).

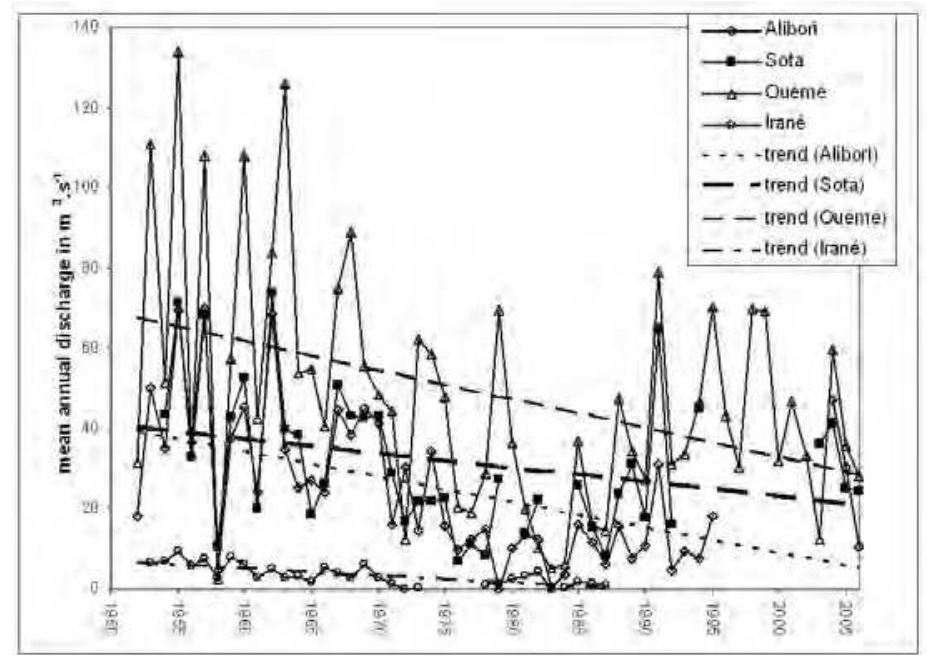

Fig. 4. The expected decrease in discharge of gauged Sudanian rivers during the Great Drought

During the end of summer 2010, the surroundings of the Niger River in the Niamey area suffered a severe flood. We show here, that although there was a partial recovery after the 
severe droughts of the 80 's and 90's, rainfall was not the main factor of this exceptional flood: 2010 annual rainfall was below the 50's 60's values, and neither rainfall distribution during the year, nor the size of the rainy events changed significantly during the last decades. Rather, the hydrological behavior of the right bank tributaries of the Niger River shows a severe increase in runoff since the 80's (Fig.3), which is still ongoing for two of them, and resulted in changes in the hydrograph of the Niger River during the rainy season, lasting from June to August in Niamey (Fig. 6). Otherwise, during the last decade (20002009), the flood occurred 2 or 3 weeks earlier at the Niamey station than in previous decades. During the last two decades, the end of the main flood has come relatively early in spite of the increase in discharge, continuing to occur 2 months earlier than in the 1950s and 1960s (before the drought) (Fig. 6). We show that this is the result of an increase in bare and crusted soils as a consequence of human pressure and/or of non reversible effects of the drought. This questions the idea of the re-greening Sahel arising from recent remote sensing studies. Of particular interest to policymakers is the effect of human pressure (and particularly intensive cropping and grazing) on hydrological regimes of Sahelian rivers, which could be partly mitigated by either the use of updated urbanization rules of by promoting re-greening experiments which had already some success in this area.

The hydrograph of Niger River downstream from the Niger Inner Delta (northern Mali) is bi-modal, being constituted by (Fig. 6):

- a first, local and sahelian flood, fed by the discharge of the sahelian right bank tributaries of the Niger River, mainly the Gorouol, the Dargol and the Sirba, as well as some small direct tributaries from both the right and the left banks; it is also called the "red" flood due to the important suspended load of lateritic origin; it lasts from July to late September;

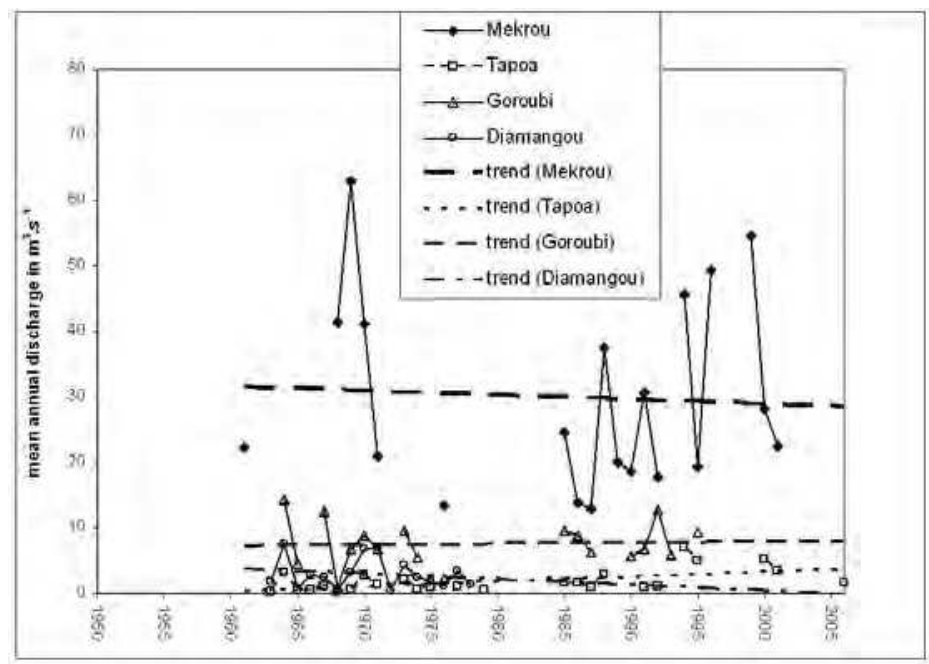

Fig. 5. The intermediate behaviour of northern Sudanian basins: towards a Hortonian process? 


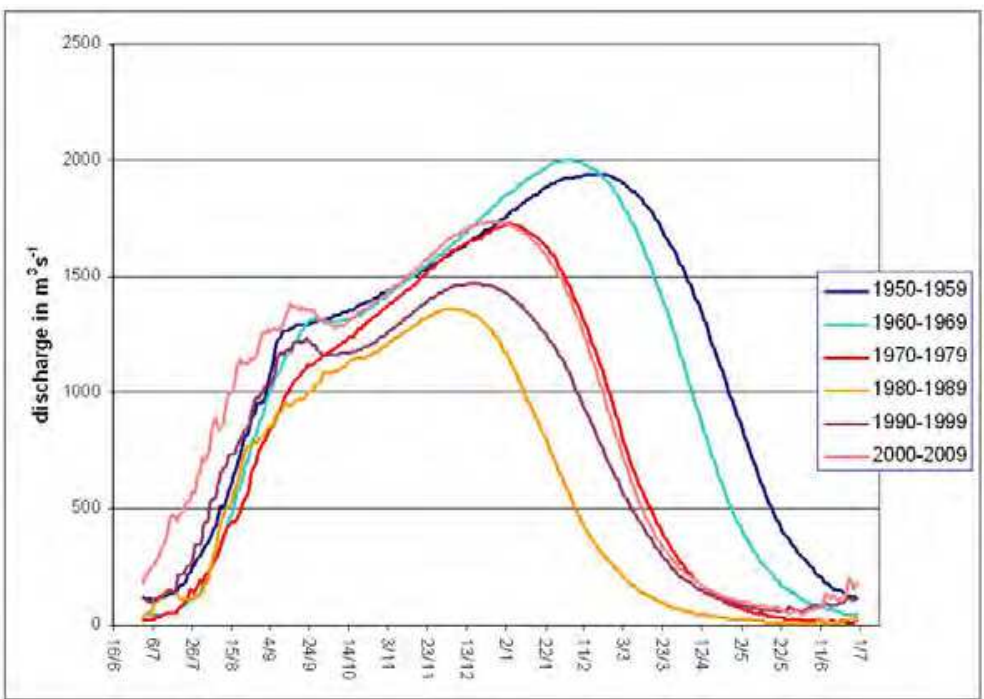

Fig. 6. Evolution of the hydrograph of Niger River at Niamey station representing the evolution of discharge and regime

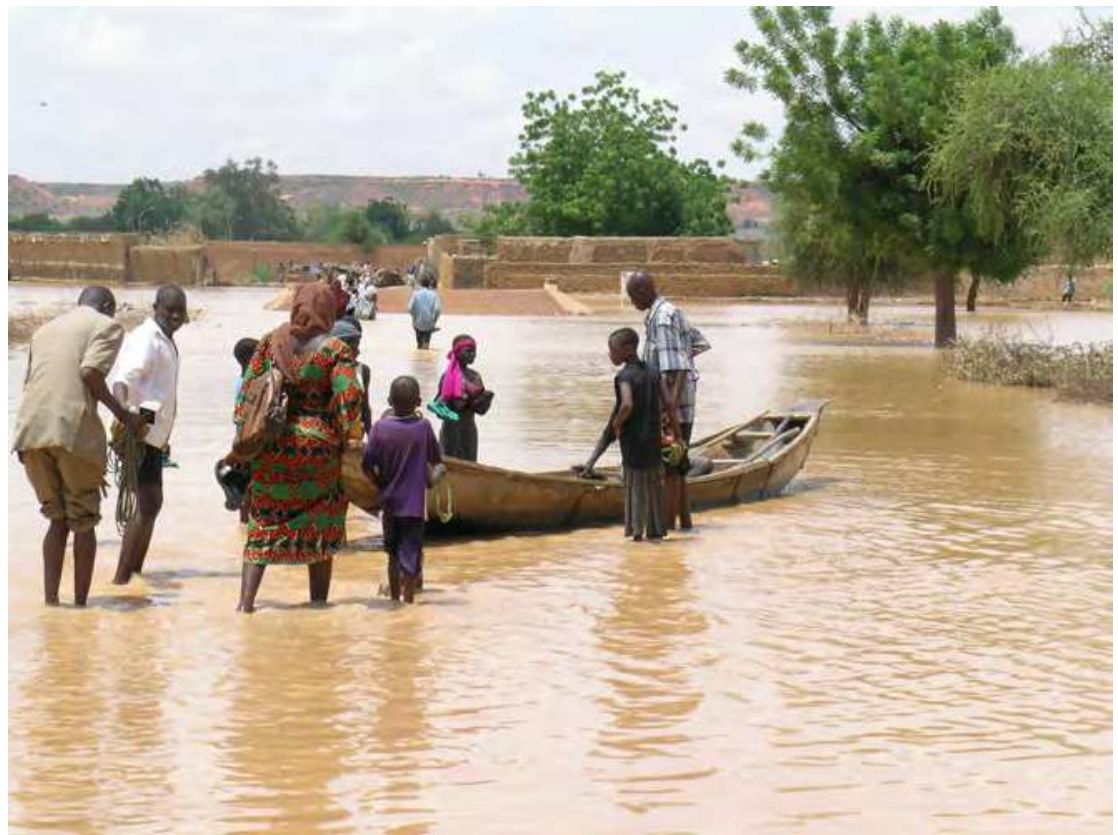

Fig. 7. Inundation of the right bank part of the city of Niamey (Niger) by the Niger River in August 2010 
- $\quad$ a second, sudano-guinean flood occurring at the beginning of October and lasting 4 to 6 months, is fed by water coming from the mountains of Guinea by the Upper Niger and its tributaries; it is called the "black" flood due to weak sediment transport (suspended load is blocked and stored in the Niger Inner Delta.

During the red flood of 2010, the water reached its highest recorded level, the flooded area was $3.1 \mathrm{~km}^{2}$ in the city of Niamey, some 5000 people lost their homes and crops and the food shortage resulting from drought of the two previous years provoked an increased havoc on local population life (Fig. 7) (Descroix et al., 2011).

\section{Influence on sedimentation}

In this section, the consequence of land use changes on erosion, transport and deposition of sediment will be analysed through the pattern of river beds evolution. As it was shown in section 2, a major land management policy was driven in the Southern French mountains at the end of the 19 ${ }^{\text {th }}$ century (as in other European Mediterranean areas, and, later, in French North African dependencies). The aim was land reclamation in order to control soil degradation as an origin of flooding and sedimentation in downstream floodplains. At the small basin scale, the results were very effective and efficient, since even very degraded hillslopes were reforested and protected against erosion (see fig. 8).
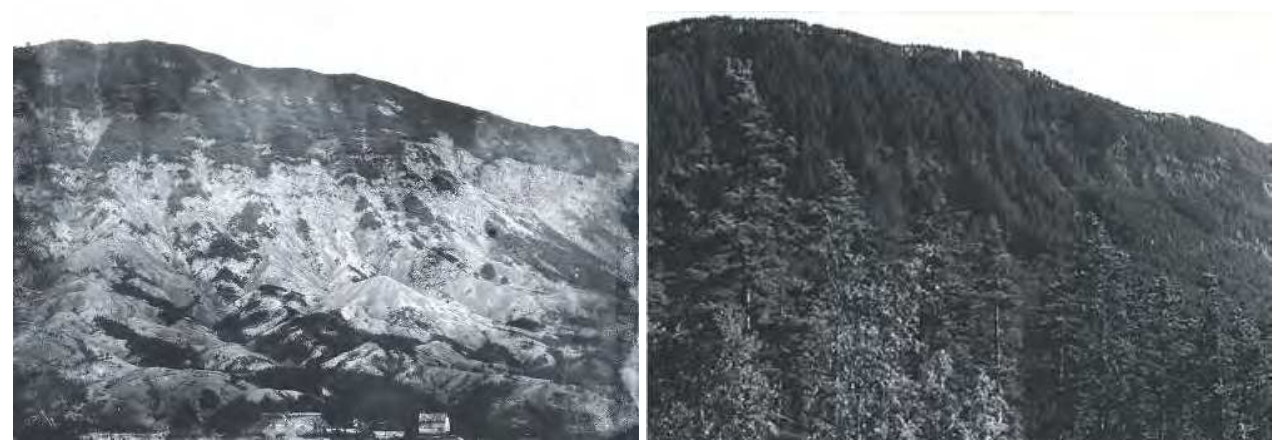

Fig. 8. The Brusquet catchment (French Southern Alps) in 1880 (left) and in 1990 (right) (photos IRSTEA (formerly CEMAGREF))

This led to important changes in the downstream hydrography, the decrease in bed load and suspended load linked to the afforestation and flood hazard reduction causing a strong evolution of river beds in most of the major rivers in the southern European mountains (Descroix and Gautier, 2002). The river beds were affected by:

- $\quad$ a reduction in river bed width;

- a river bed entrenchment;

- $\quad$ an invasion of the river bed by riparian vegetation.

These processes appeared some decades after the beginning of reforestation which was initiated in the second half of the 19th century and the rural abandonment strongly accelerated the increase in forested areas during the 20th century. During the 1970s, the first 
evidence of the sediment load deficit appeared with the beginning of the river bed entrenchment, accelerated by gravel extraction in most of the French Alps rivers. Although this activity was forbidden at the beginning of the 1980s, the river entrenchment remains severe due to the remaining sediment transport deficit linked to the natural afforestation, preventing soil material from being detached and transported. In many cases, the river bed entrenchment reached several meters, up to 3 meters in the Buech river valley (Descroix and Gautier, 2002), locally more than $10 \mathrm{~m}$ in northern French alpine rivers (Peiry, 1988). In the last decades, $90 \%$ of the total length of French Alpine rivers have been affected by this sedimentary déficit (Peiry et al., 1994). This could lead to the destruction of bridges and embankments, and led the authorities to drive new land management policies applied to river beds: new embankment, protection of bridges, etc (Fig. 9).

In Northern Mexico, the strong overgrazing and deforestation cited in section 2 are linked to speculation; it is easy to earn much money without taking into consideration the land conservation; selling wood to sawmills, and calves to the US market became good businesses during the last decades. In the 1980s and the 1990s, Durango state (Northern Mexico) produced 5 millions $\mathrm{m}^{3}$ of wood per year instead of the 1.7 million $\mathrm{m}^{3}$ authorized by federal forestry institutions (Descroix et al., 2001). During the 1990s and the beginning of the 2000s, a general trend of overgrazing was observed in the whole Northwestern part of Mexico (Chihuahua, Sonora, Sinaloa and Durango States) (Descroix, 2004).
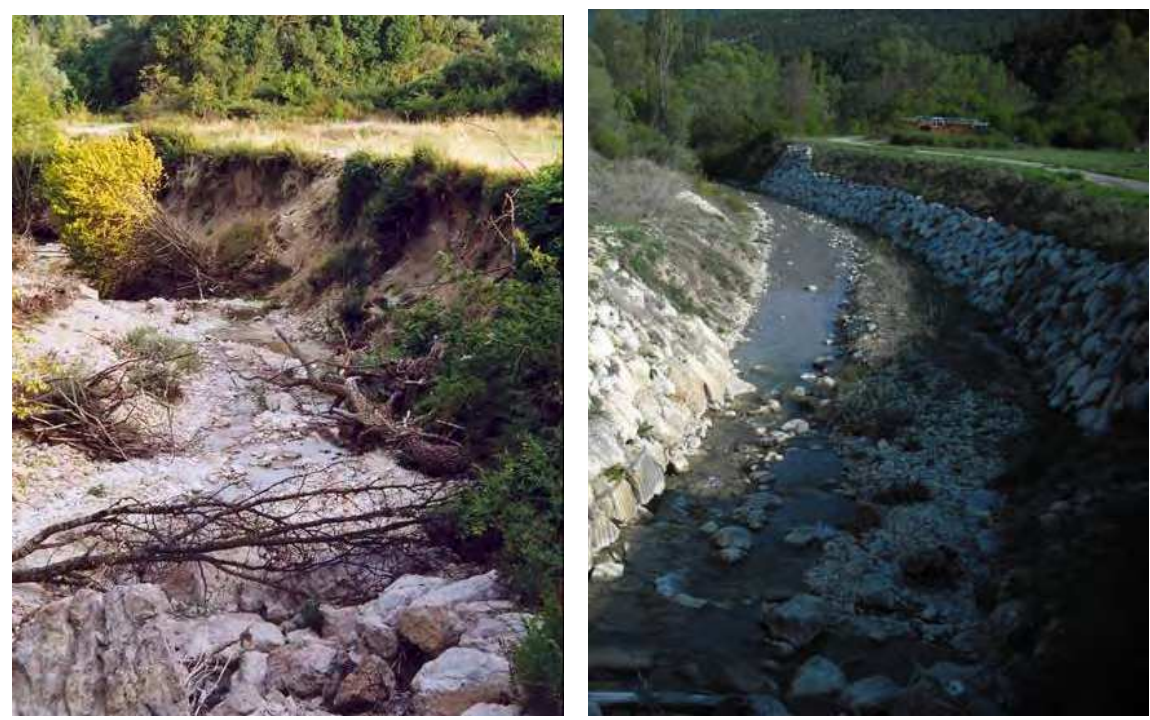

Fig. 9. The Céans river bed in 2004 (left) and in 2011 (right) (Southern French Alps). The bed of the Céans was entrenching strongly in the last decades, due to a great decrease of erosion and sediment transport. The river banks were falling regularly in the entrenched bed (left), obliging the authorities in building new embankments to protect surrounding areas from destruction (right).

This led to the on-going land degradation described in section 2. This causes a severe increase in suspended and bed load sediment in river beds, which in turn leads to the 
widening and enhancement of these beds (fig. 10a): downstream, this provokes the silting up of numerous dams located at the boundary of the coastal Sinaloa and Sonora plain (Fig. $10 \mathrm{~b}$ ); the latter being arid or semi arid, it needs water from the Western Sierra Madre to supply the irrigated districts. Clearly, land overexploitation in the upper part of the basins is threatening the agricultural and economic development of the relatively rich coastal plain, as well as the endorheic basin of the Nazas River and the Conchos basin, the main Mexican tributary of the Rio Bravo/Rio Grande River.
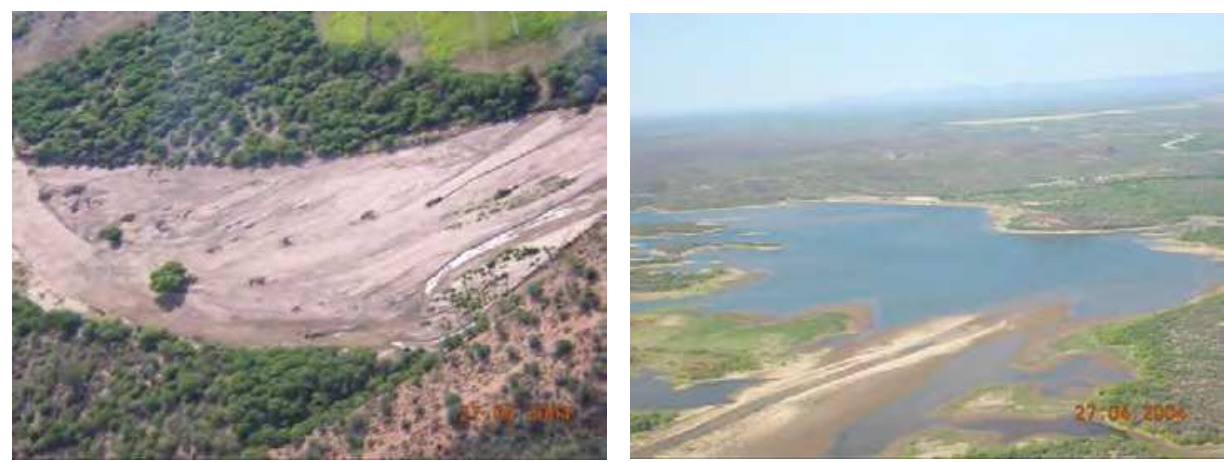

Fig. 10. Evidence of silting up in the Matapé River bed: 10a (left) a general widening and enhancement of river bed is observed; $10 \mathrm{~b}$ (right) downstream, sedimentation is filling the dams reservoirs, threatening the irrigation downstream in the Coastal, semi-arid, plain.

In section 3, we saw that West Africa is suffering a strong land use change due to both a 40 year long drought and a severe demographic pressure (the highest demographic growth in the World since the beginning of the 1990s).

What are the consequences of this pressure on the regional sedimentary balance?

There is a strong opposition in the sedimentary balance of the Niger River upstream vs downstream from the Niger Inner Delta.

- In the Bamako area (upsteam reach) a strong sedimentary deficit has been observed due to sand resource strong overexploitation; furthermore, part of the sediment load is being stored in the Selingué dam (Sankarani River, one of the main tributaries of Niger Upper reach) (Ferry and Mietton, 2011). This is recent and was not observed previously (Picouet, 1999).

- Inversely, in the downstream reach, a strong silting up of the Niger's riverbed has been observed, linked to both the severe increase in soil erosion in the Sahelian basin and the significant decrease in Niger river discharge (-50\% after 1968). (Amogu, 2009, Amogu et al., 2010) (Fig.11).

The sedimentary deficit of the Niger riverbed upstream from Bamako is also evidence of the impact of urbanisation on the hydrological behaviour of river basins.

Like the Niger River, some other great river basins in the world are affected by changes in sedimentary balance; the following examples show the importance of taking into account this balance in developing land management policies: 

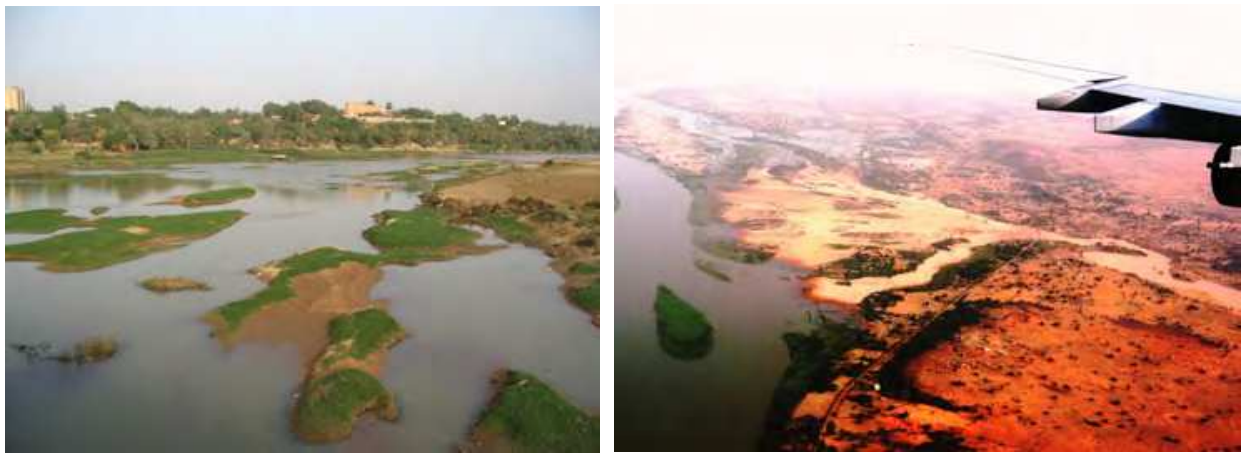

Fig. 11. Evidence of the silting up of Niger River in its middle reach: at left, sandy deposit in the river bed at Niamey (Niger); at right: the new Kourtéré (formed in 1998) alluvial cone invading the Niger River bed in its right bank, just upstream from Niamey (photo $E$. Gautier)

- $\quad$ The Nile River: all the sediment is stored in the Upper Aswan dam (total capacity 169 billion $\mathrm{m}^{3}$ ), thereby retaining sediment that could fertilize the lower part of the valley, where this fertile sediment would ensure good harvests in a time of demographic growth. This sediment retention also caused a strong decrease in the volume of fisheries in the mouth of the Nile River, due to the reduction of nutrients, retained in the dam. In addition, the overuse of Nile River water for irrigation causes a salinization of the lower part of the river, the low stream flow allowing sea water to enter the delta and the lower river bed.

- $\quad$ As the Nile, the Volta River in West Africa, is equipped with one of the biggest dams in the world (Akosombo dam, 160 billions $\mathrm{m}^{3}$ stored); but with all the alluvium being blocked in the dam, the sediment balance became negative some decades ago as a feed back effect. The littoral area east of the Volta River's mouth in the Gulf of Guinea is suffering a strong erosion and the shore is receding, in some places more than $30 \mathrm{~m}$ per year, obliging fishermen in the coastal areas of Togo and Benin to regularly move their villages back;

- The Yellow river in northern China (Huang He) is known to have the highest suspended and bed load in the world, mostly due to the erosion of very fertile but very fragile loess plateau soil. The combination of silting up in the riverbed and the overexploitation of stream water flow, evidenced by the building of some dams (San Men, Liujiaxia, Qingtongxia among others) have caused the river to not reach the sea for periods lasting several months per year since the beginning of the 2000s (Lasserre \& Descroix, 2011).

In these three cases, an increase in the silting up in the cited dams is observed.

\section{Specific impacts of agriculture and urbanisation}

In this section, we will study other human factors that influence the modification of hydrological behaviour, such as agriculture, irrigation, drainage, urbanisation and socioeconomics, in several parts of the World (mainly in tropical areas). 
As has been shown in section 4, rural activities (mostly cropping, livestock grazing and forest clearing) are commonly the cause of an increase in soil losses in the hillslopes, due to the consequent decrease in vegetation cover which causes a soil direct exposure to wind and water erosion. Even if the crops can reach or exceed the same biomass as the removed natural vegetation, this is the case only at the end of the cropping season: evapotranspiration, soil coverage, and protection against wind and water erosion and against runoff remains low during the first weeks and months of the crop cycle. Seasonal influence also impacts deforestation, and clearing has little effect on flow under moderate climates during winter and early spring, because in these seasons, evapotranspiration is very low (Kuchment, 2008).

The impact of irrigation on the water cycle is particularly significant in arid areas, but it is also considerable in moderate climates; it is common for runoff and evaporation from irrigated areas to increase significantly (Kuchment, 2008). In many dry areas, a rise in water table can occur because of water filtration from reservoirs, leakage from water distributing systems or inappropriate practices; this may cause waterlogging and soil salinisation (Kuprianov and Shiklomanov, 1973; Kuchment, 2008). In order to avoid water logging, drainage is applied in many regions of the world; the first effect of drainage is the lowering of water table; as a result, evapotranspiration may drop considerably; it increases flow velocities and runoff can rise by $20-30 \%$. The effect of agriculture and forestry on the water cycle depends on physiographic and climatic conditions. Ploughing usually breaks up overland flow and increases infiltration (Kuchment, 2008). Tillage and the activity of plant roots system modify the structure of the upper soil layer and change the vertical permeability and the soil water retention capacity. Extension of vegetation cover increases the interception of precipitation and increases evapotranspiration.

Urbanisation is well known to disturb natural hydrology, mostly due to the reduction in infiltration capabilities and in the obstruction of stream flows. The increasing urbanisation of watersheds increases the amount of impervious areas; thereby increasing the volumes of stream flow and shortening the time of rain water concentration. The consequence is an increase in maximum flow discharges thereby increasing the flooding risk (Kuprianov and Shiklomanov, 1973). Natural land that used to soak up runoff is replaced by roads and large areas of pavement. Due to the increased pavement area, there is more storm runoff and erosion because there is less vegetation to impede the flow of water as it runs down hills; more land erosion and more sediment is washed into streams, less water will soak into the ground. This means that the water table will have less water to recharge it; it can cause subsidence of the urban area, which is commonly exaggerated by the overuse of ground water for urban needs. Mexico City pumps almost 1.5 billion $\mathrm{m}^{3} \cdot \mathrm{yr}^{-1}$ from its water table, provoking a subsidence of several $\mathrm{cm}$ per year. Otherwise, large areas of Bangkok became liable to flooding in the recent decades due to the subsidence caused by the overuse of groundwater.

Thus, urbanisation causes an increase in both the runoff coefficient and the stream velocity due to the increasing proportion of impervious surfaces (factories, roofs, roads, car parks, pavements, etc). It also causes strong modifications in water quality, rain water draining these impervious areas and loading urban and industrial dust and wastes through the rivers and the water tables. 
As has been shown in section 3, urbanisation needs gravel and sand for construction and river beds have long been considered as abundant supplying areas for these materials. However, these reserves are not inexhaustible; uncontrolled extraction of material may affect the sediment balance and the hydraulic equilibrium of the river, and sometimes that of surrounding lands, bridges and embankments. These consequences are amplified in mountainous areas due to the steep slopes.

A case study of consequences of mountain urbanisation: the La Ravoire torrent (Northen French Alps) appearance in March 1981.

At the end of March 1981 a major ecological catastrophe occurred in the French northern Alps. At the snowmelt, the $31^{\text {st }}$ March, the Ravoire brook (Upper Isère valley, in Savoie region) suddenly reawakened (Périnet, 1982) (Fig.12).

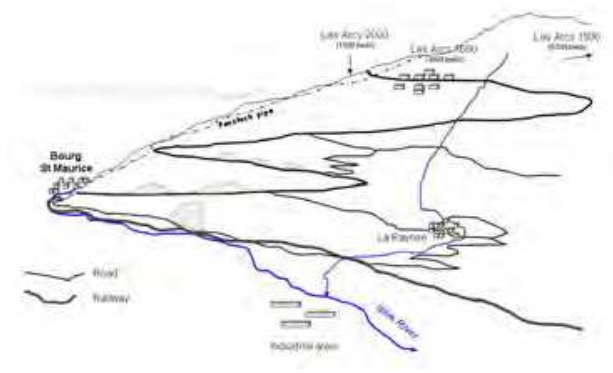

(a)

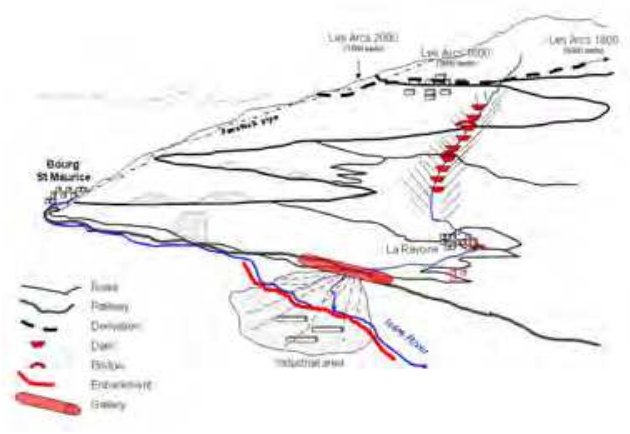

(c)

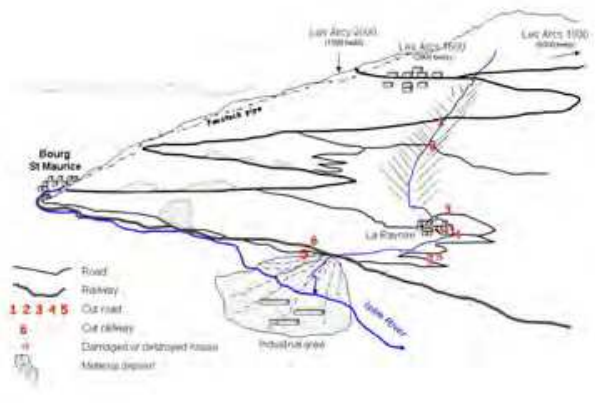

(b)

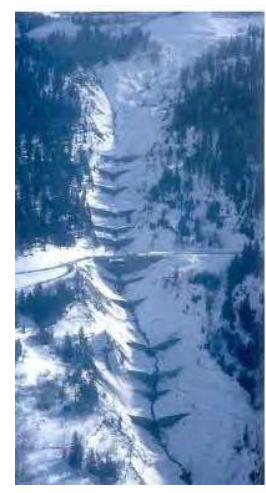

(d)

Fig. 12. a) Situation of the Les Arcs hillslope before the 31/3/1981; b) Situation after the 31/3/1981: damages caused by the rainy event; c) Main restoration measures; d) the series of dams built to prevent further deepening of the torrent bed (photo F. Périnet) 
The banks were destabilized and collapsed in great bundles and the brook became a torrent, carrying enormous volumes of mud mixed with snow, trees and rocks. Within five days, its bed had deepened by more than 10 meters; $300000 \mathrm{~m}^{3}$ of rocks and material hurtled down from the mountain, covering more than 5 hectares of grassland at foothill, blocking the Isère River and pushing its course towards its right bank, in the industrial area of Bourg Saint Maurice. Significant damages were recorded in this area with some buildings destroyed; on the left bank of Isère River, where the Ravoire brook flows, the railway and five roads (including the access road to Les Arcs ski station) were cut, five houses partially or completely destroyed. In a first assistance operation, a single way road was established to provide access to the 15000 stranded tourists trying to leave the ski station, the torrent water was diverted towards the penstock pipe of the Malgovert hydropower station (located near Bourg St Maurice in the bottom of the Isère valley). Then works for the torrent course reclamation, the housing protection and the building of new bridges were undertaken as well as a gallery for the railroad (Fig.12).

\section{Geopolitics}

Geopolitical events can significantly impact the water cycle. The main concern is the strong land use changes caused by massive migrations due to wars or local conflicts.

"The Indochinese section of the Mekong Basin has been subjected to major environmental disturbances over the last half century" (Lacombe et al., 2010). The Vietnam War is invoked as a central explanation for the extensive deforestation in specific areas while conflict induced exoduses caused the abandonment of cultivated lands, followed by forest regeneration. Although the socio-economic consequences of these episodes have been analysed, their hydrological impacts remained unknown until the study of Lacombe et al. (2010). They investigated hydrological changes in two catchments of the lower Mekong Basin that were either heavily bombed (in southern Laos) or depopulated (in northern Laos) (Fig.13). The first one is located on the Ho Chi Minh trail; one third of the latitudinal extent of the Ho Chi Minh trail in Laos is included in this southern catchment and it was a target which the United States Air Forces (USAF) made a concerted effort to neutralize. During this conflict, the USAF practised deliberate massive removal of vegetation as a military tactic to deny cover and land to opposition forces. A total of between 690000 and 2948000 tons of high explosive ordnance were exploded over this southern catchment between October 1965 and September 1973 (Lacombe et al., 2010). In the northern basin, while air operations of the Vietnam War caused losses of forest, continuing ground battles in northern Laos over the period 1953-1975 induced significant emigration. Between 730000 and 1 million people (one fourth of the country's population as per 1970) were displaced over this period (Taillard, 1989; Goudineau, 1997; cited by Lacombe et al., 2010). This migration flow was sustained after the end of the war. As an immediate consequence of the communist takeover more than 300000 people fled to Thailand between 1975 and 1985, escaping the new regime. This massive exodus particularly affected the northern provinces of Laos, traditionally inhabited by Hmong ethnic groups (Central Intelligence Agency, 1970, cited by Lacombe et al., 2010) which served the US army during the Vietnam War and were forced to flee the new communist regime after the war ended. The abandonment of large mountainous areas, which were traditionally subject to shifting or permanent cultivation, most likely induced a shift toward forest regeneration (Lacombe et al., 2010). The analysis (Lacombe et al., 2010) is 
based on the widely and independently recognized fact that vegetation, via evapotranspiration, is a central driver of groundwater recharge and stream flow production. The analysis of the most complete Vietnam War air mission database and of available hydrometeorological data over the period 1960-2004 reveals a sharp runoff increase in the southern catchment when bombing climaxed in the early 1970s while no hydrological change is observed in the northern catchment over the same period (Lacombe et al., 2010). From 1995 onwards, the northern and southern catchment's runoff productions are significantly lower and higher than in the pre-war conditions, respectively. Although causalities could not be ascertained because of data limitations, these short- and long-term hydrological shifts were found to be consistent, in terms of occurrence, spatial distribution and magnitude, with the expected changes in the vegetation cover, either denser in the north (in response to abandonment of cultivated lands) or sparser in the south (as a result of bomb-induced deforestation and soil degradations) (Lacombe et al., 2010). Furthermore, as a consequence, some areas near Vientiane (the capital of Laos) and overall near Luang Prabang (a city located $200 \mathrm{~km}$ north of Vientiane) were cleared in past years including on steep slopes (Chaplot et al., 2007), causing the appearance of gullies (Fig.14).

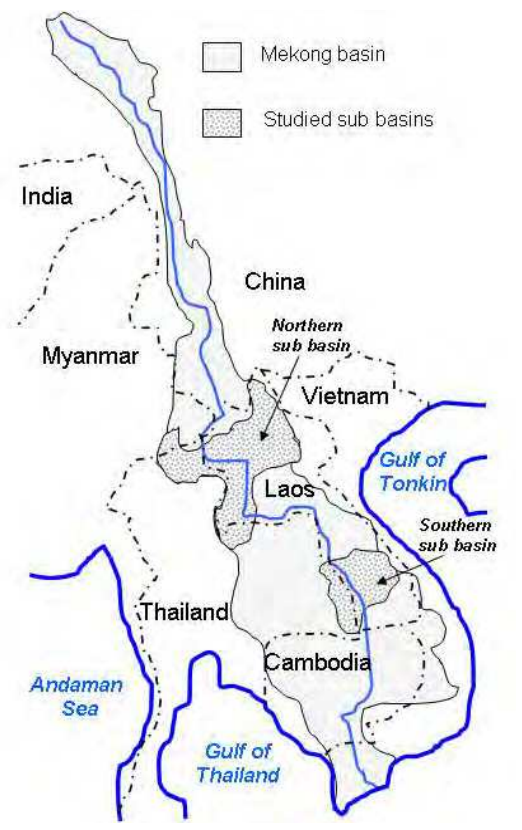

Fig. 13. Location of the two sub basins studied by Lacombe et al. 2010

In other areas in the world, geopolitics could lead to severe land degradation: in the Republic of South Africa, the apartheid regime created some Bantustans, also known as black African homelands or simply homelands), which were territories set aside for black inhabitants, not recognized by the international community. Due to population density and land management, soil erosion was strong in some of these areas such as the Kwazulu. The same kind of process occurred in northern Pakistan during the USSR-Afghanistan war; a great number of Afghans took refuge in Pakistan. Finally, in Hispaniola Island (West 
Indies), which includes two countries, Haïti on the western side and the Dominican Republic to the east, the rural areas of the Republic of Hairti, are much more densely populated than the ones of the Dominican Republic resulting in severe land degradation (deforestation to harvest crops, grass and wood). The fact that the population is much poorer in Haiti should also be noted. In these three examples, there is a strong gradient in land exploitation between two areas, noticeable in aerial pictures and satellite scenes. Overall, this provokes severe damages in the overexploited side due to cyclones in Haïti and to monsoon rains in Pakistan and in South Africa.

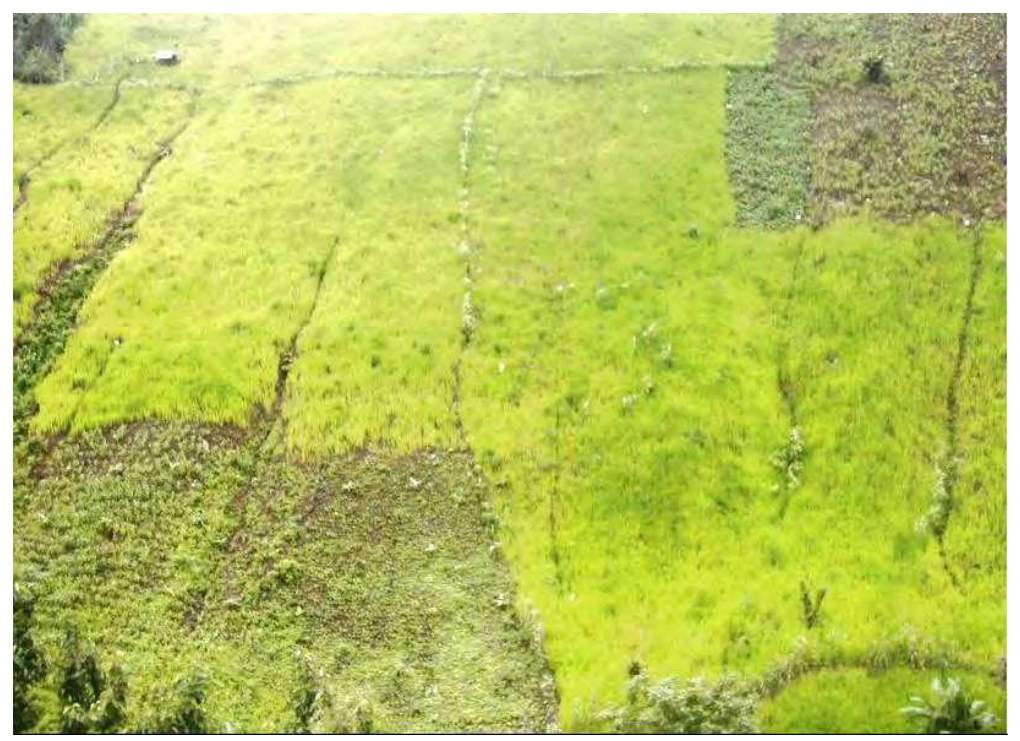

Fig. 14. Gullies appearing in rain fed rice fields in central Laos, $10 \mathrm{~km}$ eastward from Luang Prabang. These areas were settled on fields recently cleared by peasants coming from the eastern Laotian mountains near the Vietnam boundary, judged insecure by the government which encouraged people to migrate within easily controlled areas (photo NAFRI) .

\section{Conclusion}

These last two types of human impacts (urbanisation and geopolitics) demonstrate the great influence of societies, socio-economic conditions, the strategic context and the migration processes, on the land cover and thus on the water cycle. The poor understanding of the influence of these factors could lead to exaggerations recorded in history, such as the sentencing of goats as "the main enemy of Mediterranean forests and soils" by the French governments during the $19^{\text {th }}$ century, while most of the land degradation problem could result from the lack of forest policy during the period just after the French Revolution (from 1797 to 1804) and the forest exploitation during previous centuries in order to build the ships of the French Royal Marine. The Little Ice Age (from the end of Middle Age to the end of 19th century) and its low winter temperatures (mostly during the 19th century) was also a natural constraint for the vegetation. It is always more appropriate to link these severe crises of water cycle to a combination of natural and human factors. 


\section{Acknowledgements}

We are grateful to the French research Institute for Development (IRD), the Niger Basin Authority (NBA), and the AMMA program which funded the field experiments in Mexico, in France and in Niger. This study was also partially funded by the French ANR projects ECLIS (Contribution of livestock to the reduction of rural population vulnerability and to the promotion of their adaptability to climate and society changes in Sub-Saharan Africa) and ESCAPE (Environmental and Social Changes in Past, present and future)

\section{References}

Albergel, J. (1987) Sécheresse, désertification et ressources en eau de surface : application aux petits bassins du Burkina Faso. In The Influence of Climate Change and Climatic Variability on the Hydrologic Regime and Water Resources; IAHS publication $N^{\circ} 168$, Wallingford, UK, pp. 355-365.

Ali, A. \& Lebel, T. (2009) The Sahelian standardized rainfall index revisited. Int. J. Climatol. 29, 1705-1714.

Amani, A. \& Nguetora, M. (2002) Evidence d'une modification du régime hydrologique du fleuve Niger à Niamey. In FRIEND 2002 Regional Hydrology: Bridging the Gap between Research and Practice, Proceedings of the Friend Conference, Cape Town, South Africa, 18-22 March, 2002; Van Lannen, H., Demuth, S., Eds.; IAHS publication $\mathrm{N}^{\circ} 274$, Wallingford, UK, pp. 449-456.

Amogu, O. (2009). The land degradation in the sahel and its consequences on the sediment balance of the Mid Niger River PhD thesis, university Grenoble 1, $420 \mathrm{p}$.

Amogu O., Descroix L., Yéro K.S., Le Breton E., Mamadou I., Ali A., Vischel T., Bader J.-C., Moussa I.B., Gautier E., Boubkraoui S..\& Belleudy P. (2010) Increasing River Flows in the Sahel?. Water, 2(2):170-199.

Andersen, I., Dione, O., Jarosewich-Holder, M.\& Olivry J.C. (2005) The Niger River Basin: a Vision for Sustainable Management, Golitzen, K.G., Ed., The World Bank: Washington, DC, USA.

Cappus, P. (1960). Etude des lois de l'écoulement. Application au calcul et à la prévision des débits. Bassin expérimental d'Alrance. La Houille Blanche, No. A. Grenoble, France, pp. 521-529.

Chaplot, V., Khampaseuth, X., Valentin, C., \& Le Bissonnais, Y. (2007). Interrill erosion in the sloping lands of northern Laos submitted to shifting cultivation. Earth Surface Processes and Landforms, 32, 415-428.

Descroix, L., Viramontes, D., Vauclin, M. , Gonzalez Barrios, J.L. and Esteves, M. (2001). Influence of surface features and vegetation on runoff and soil erosion in the western Sierra Madre (Durango, North West of Mexico). Catena. 43-2 :115-135.

Descroix, L., Gonzalez Barrios, J.L., Vandervaere, J.P., Viramontes, D. \& Bollery, A. (2002). An experimental analysis of hydrodynamic behaviour on soils and hillslopes in a subtropical mountainous environment (Western Sierra Madre, Mexico). Journal of Hydrology, 266:1-14.

Descroix, L. \& Gautier, E. (2002). Water erosion in the French Southern Alps : climatic and human mechanisms. Catena, $50: 53-85$. 
Descroix, L. \& Mathys, N. (2003). Processes, spatio-temporal factors and measurements of current erosion in French Southern Alps: a review. Earth Surface Processes and Landforms. 28 ; 993-1011.

Descroix L. (2004) : Sintesis de las observaciones de Luc Descroix en cuanto a los Términos de Referencia para el "Estudio de factibilidad del proyecto de Restauración y Conservación de suelo e incremento de la cobertura vegetal para aumentar la recarga de los acuíferos de la cuenca del Río Sonora ». Comisión Nacional del Agua, Subdirección General Técnica, World Meteorological Organisation. Research and Technical Report, $54 \mathrm{p}$.

Descroix, L., Mahé, G., Lebel, T., Favreau, G., Galle, S., Gautier, E., Olivry, J-C., Albergel, J., Amogu, O., Cappelaere, B., Dessouassi, R., Diedhiou, A., Le Breton, E., Mamadou, I. \& Sighomnou, D. (2009). Spatio-Temporal Variability of Hydrological Regimes Around the Boundaries between Sahelian and Sudanian Areas of West Africa: A Synthesis. J. Hydrol, 375, 90-102.

Descroix, L., Laurent, J-P., Boubkraoui, S., Ibrahim, B., Cappelaere, B., Favreau, G., Mamadou, I., Le Breton, E., Quantin, G. \& Boulain, N. (2012). Experimental evidence of deep infiltration under sandy flats and gullies in the Sahel. J. Hydrol. (2012), doi:10.1016/j.jhydrol.2011.11.019

Descroix, L., Genthon, P., Amogu, O., Sighomnou, D., Rajot, J-L., Vauclin, M. (2011). Recent hydrological changes of Sahelian rivers: the case of the 2010 red floods of the Niger River at Niamey. AGU conference, San Francisco, CA, USA

Ferry, L. \& Mietton, M. (2011). L'équilibre du fleuve Niger perturbé. Sciences au Sud, 60, 3.

Hewlett, J.D. (1961). Soil moisture as a source of base flow from steep mountain watershed. US forest Service, Southeastern Forest Experiment Station, Asheville, North Caroline.

Horton, R.E. (1933) The role of infiltration in the hydrologic cycle. EOS. American Geophysical Union Transactions 14, 44-460.

Kuchment, L.S. (2008). Runoff generation (genesis, models, prediction), Water problems institute of RAN, 394p. (in Russian).

Kuprianov V.V. \& Shiklomanov, I.A. (1973). Influence d el'urbanisation, de l'industrie er de l'agriculture sur le cycle hydrologique. Acts of the meeting "Hydrological problems in Europe » Bern, Switzerland, August 1973, UNESCO \& WMO.

Lacombe, G. Pierret,A. Hoanh, C.T., Sengtaheuanghoung, O. \& Noble, A.D. (2010). Conflict, migration and land-cover changes in Indochina: a hydrological assessment. Ecohydrol. 3, 382-391 (2010) Published online 1 October 2010 in Wiley Online Library (wileyonlinelibrary.com) DOI: 10.1002/eco.166.

Lasserre, F. \& Descroix, L. (2011). Eaux et Territoires. third edition, Presses Universitaires du Québec, ISBN 978-2-7605-2602-0, Sainte Foy, Québec, Canada.

Lebel, T. \& Ali, A. (2009) Recent trends in the Central and Western Sahel rainfall regime (1990-2007). J. Hydrol. 375, 90-102.

Leblanc, M., Favreau, G., Massuel, S., Tweed, S., Loireau, M. \& Cappelaere, B. (2008) Land clearance and hydrological change in the Sahel: SW Niger. Glo Pla Cha 61, 49-62.

Leduc, C., Bromley, J. \& Shroeter, P. (1997) Water table fluctuation and recharge in semi-arid climate: some results of the HAPEX Sahel hydrodynamic survey (Niger). J. Hydrol. 188-189, 123-138. 
Mahé, G. (1993) Les écoulements fluviaux sur la façade Atlantique de l'Afrique. Etude des éléments du bilan hydrique et variabilité interannuelle. Analyse de situations hydroclimatiques moyennes et extrêmes. Etudes et Thèses, Orstom, Paris.

Mahé, G., Leduc, C., Amani, A., Paturel, J-E., Girard, S., Servat, E. \& Dezetter, A. (2003) Augmentation récente du ruissellement de surface en région soudano sahélienne et impact sur les ressources en eau. In Hydrology of the Mediterranean and Semi-Arid Regions, proceedings of an international symposium. Montpellier (France), 2003/04/1-4, Servat E., Najem W. , Leduc C., Shakeel A. (Ed.) :, Wallingford, UK, IAHS, 2003, publication $\mathrm{n}^{\circ} 278$, p. 215-222..

Mahé, G., Paturel, J.E., Servat, E., Conway, D. \& Dezetter, A. (2005) Impact of land use change on soil water holding capacity and river modelling of the Nakambe River in Burkina-Faso. J. Hydrol. 300, 33-43.

Mahé, G. (2009) Surface/groundwater interactions in the Bani and Nakambe rivers, tributaries of the Niger and Volta basins. West Africa. Hydrol. Sci. J., 54, 704-712.

Mahé, G. \& Paturel, J-E. (2009) 1896-2006 Sahelian annual rainfall variability and runoff increase of Sahelian rivers. C.R. Geosciences, 341, 538-546.

Mahé, G., Lienou, G., Bamba, F., paturel, J-E., Adeaga, O., Descroix, L., Mariko, A., Olivry, JC., Sangaré, S., Ogilvie, A., and Clanet, J-C. (2011). The Niger River and climate change over 100 years. Hydro-climatology: variability and change; proceedings of symposium J-H02 held during IUGG 2011, Melbourne, Australia, july 2011, IAHS Publ n³44, 2011.

Olivry, J-C. (2002). Synthèse des connaissances hydrologiques et potentiel en 862 ressources en eau du fleuve Niger. World Bank, Niger Basin Authority, 863 provisional report, 160 p, Niamey.

Peiry, J-L. (1988). Approche géographique spatio-temporelle des sediments d'un cours d'eau intra-montagnard: l'exemple de la plaine alluviale de l'Arve (Haute Savoie, France) ; PhD thesis, Lyon 3 University, 378pp.

Peiry, J-L., Salvador, P.G. \& Nouguier, F. (1994). L'incision des rivières dans les Alpes du nord: état de la question. Revue de Géographie de Lyon, 69 (1), 47-56.

Périnet, F. (1982). Stations de sport d'hiver; réflexionc à propos d'un accident. Revue Forestière Française, 34 (5), 99-111.

Picouet, C. (1999). Géodynamique d'un hydrosphère tropical peu anthropisé: Le Bassin supérieur du Niger et son delta intérieur. PhD Thesis, University Montpellier 2, 469 p.

Séguis, L., Cappelaere, B., Milési, G., Peugeot, C., Massuel, S. \& Favreau. G. (2004) Simulated impacts of climate change and land-clearing on runoff from a small Sahelian catchment. Hydrol. Process. 18, 3401-3413.

Tschakert, P., Sagoe, R., Ofori-Darko, G. \& Nii-Codjoe, S. (2010) Floods in the Sahel: an analysis of anomalies, memory and anticipatory learning. Climatic Change, 103: 471502.

Viramontes, D. and Descroix, L. (2003). Variability of overland flow in an endoreic basin of northern Mexico: the hydrological consequences of environment degradation. Hydrological Processes, 17 :1291-1306. 


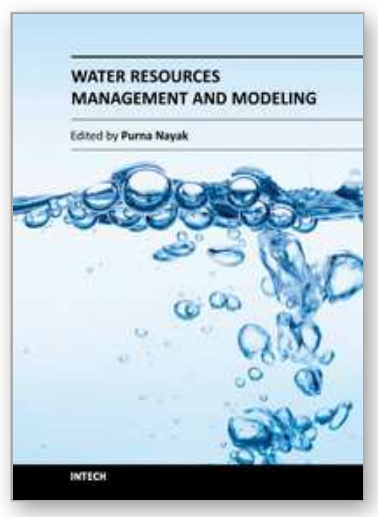

\author{
Water Resources Management and Modeling \\ Edited by Dr. Purna Nayak
}

ISBN 978-953-51-0246-5

Hard cover, 310 pages

Publisher InTech

Published online 21, March, 2012

Published in print edition March, 2012

Hydrology is the science that deals with the processes governing the depletion and replenishment of water resources of the earth's land areas. The purpose of this book is to put together recent developments on hydrology and water resources engineering. First section covers surface water modeling and second section deals with groundwater modeling. The aim of this book is to focus attention on the management of surface water and groundwater resources. Meeting the challenges and the impact of climate change on water resources is also discussed in the book. Most chapters give insights into the interpretation of field information, development of models, the use of computational models based on analytical and numerical techniques, assessment of model performance and the use of these models for predictive purposes. It is written for the practicing professionals and students, mathematical modelers, hydrogeologists and water resources specialists.

\title{
How to reference
}

In order to correctly reference this scholarly work, feel free to copy and paste the following:

Luc Descroix and Okechukwu Amogu (2012). Consequences of Land Use Changes on Hydrological Functioning, Water Resources Management and Modeling, Dr. Purna Nayak (Ed.), ISBN: 978-953-51-0246-5, InTech, Available from: http://www.intechopen.com/books/water-resources-management-andmodeling/consequences-of-land-use-changes-on-hydrological-functioning

\section{INTECH}

open science | open minds

\section{InTech Europe}

University Campus STeP Ri

Slavka Krautzeka 83/A

51000 Rijeka, Croatia

Phone: +385 (51) 770447

Fax: +385 (51) 686166

www.intechopen.com

\section{InTech China}

Unit 405, Office Block, Hotel Equatorial Shanghai

No.65, Yan An Road (West), Shanghai, 200040, China

中国上海市延安西路65号上海国际贵都大饭店办公楼 405 单元

Phone: +86-21-62489820

Fax: $+86-21-62489821$ 
(C) 2012 The Author(s). Licensee IntechOpen. This is an open access article distributed under the terms of the Creative Commons Attribution 3.0 License, which permits unrestricted use, distribution, and reproduction in any medium, provided the original work is properly cited. 